
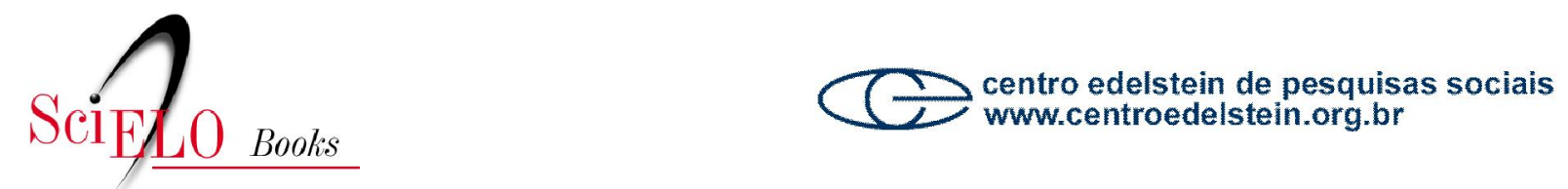

\title{
The Federal Republic of Germany
}

\author{
Helmut Zeittrager
}

SciELO Books / SciELO Livros / SciELO Libros

ZEITTRAGER, H. The Federal Republic of Germany. In SORJ, B., CANTLEY, M., and SIMPSON, K., eds. Biotechnology in Europe and Latin America: prospects for co-operation [online]. Rio de Janeiro: Centro Edelstein de Pesquisas Sociais, 2010. pp. 53-67. ISBN: 978-85-7582-036-6. Available from SciELO Books $<$ http://books.scielo.org $>$.

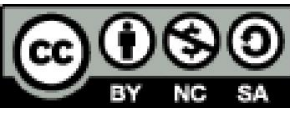

All the contents of this chapter, except where otherwise noted, is licensed under a Creative Commons Attribution-Non Commercial-ShareAlike 3.0 Unported.

Todo o conteúdo deste capítulo, exceto quando houver ressalva, é publicado sob a licença Creative Commons Atribuição Uso Não Comercial - Partilha nos Mesmos Termos 3.0 Não adaptada.

Todo el contenido de este capítulo, excepto donde se indique lo contrario, está bajo licencia de la licencia Creative Commons Reconocimento-NoComercial-CompartirIgual 3.0 Unported. 


\subsection{THE FEDERAL REPUbLiC OF GERMANY}

Helmut Zeittrager

\section{Introduction}

The government of the FRG was one of the first to recognise the strategic significance of biotechnology. By 1974 the BMFT (Bundesministerium für Forschung und Technologie) had already begun the promotion of biotechnology. Dechema (Deutsche Gesellschaft für Chemisches Apparatwesen), an industrial representative body for the chemical industry played a role in dissemination of information and in 1978 was instrumental in founding EFB, European Federation of Biotechnology.

The German Biotechnology Co-ordinating Committee, Arbeitsgemeinschaft Biotechnologie, was founded in 1978 and acts to integrate biotechnology activities in both industry and academie sectors. The first German biotechnology programme, the 'Leistungsplan' (Performance Plan) was launched in 1979. It incorporated many of the key proposals made by Dechema in collaboration with the BMFT. In the period 1979-84 a total of US\$350 million was allocated to biotechnology. include:

Other government departments supporting research in biotechnology

- Deutsche Forschungsgemeinschaft, DFG, who focus on basic research. In 1984 bioscience funding accounted for US\$107 million, one third of the total funding. DFG is an association of universities funded by local and federal government.

- BMWi, Federal Ministry for the Economy.

- BML, Federal Ministry for Agriculture.

The BMFT is keenly aware of both the opportunities and risks presented by biotechnology. Their position is summarised in a booklet obtainable from the BMFT in Bonn, FRG.

In a major policy speech in May 1983, the Chancellor defined the government position with regard to biotechnology:
Our society needs technical progress. Globally, developments are taking place at a furious pace, in the information and communications technologies, in new production techniques, in biotechnology and in the development of new materials. These offer opportunities, but also carry with them dangers. We know that not everything that is humanly possible is suitable for mankind. This is the challenge which we have to face. We must seek to remain master of the technology.

The Federal government subsequently drew up a programme for applied biological and biotechnological research for the period 1985-88. Biotechnology was given a central innovative role among the applied sciences. The following research objectives were defined:

- to promote top quality science in areas relevant to the future competitiveness of the state.

- to evaluate opportunities and hazards, introducing appropriate safety regulations and debating ethical considerations at an early stage of progress.

- to promote the training of a new generation of biotechnologists.

FEDERAL FUNDING

At the beginning of 1986 it was announced that the total Federal funding for the period 1984 to 1989 would be increased to DM 1.14 billion. Roughly $1 / 3$ was targeted to institutions and another $1 / 3$ to four new gene centres, other centres of excellence and infrastructure, including support for new biotech ventures. The bulk of the remaining money is designated for development of facilities in 'bottleneck' areas such as cell culture technology, fermentation, enzymology, plant biotechnology etc.

One of the essential components of the present funding is a generous investment in the essential enabling science for biotechnology. The federal government has accepted that this is essential if the commercial focus of biotechnology is to be mastered. 


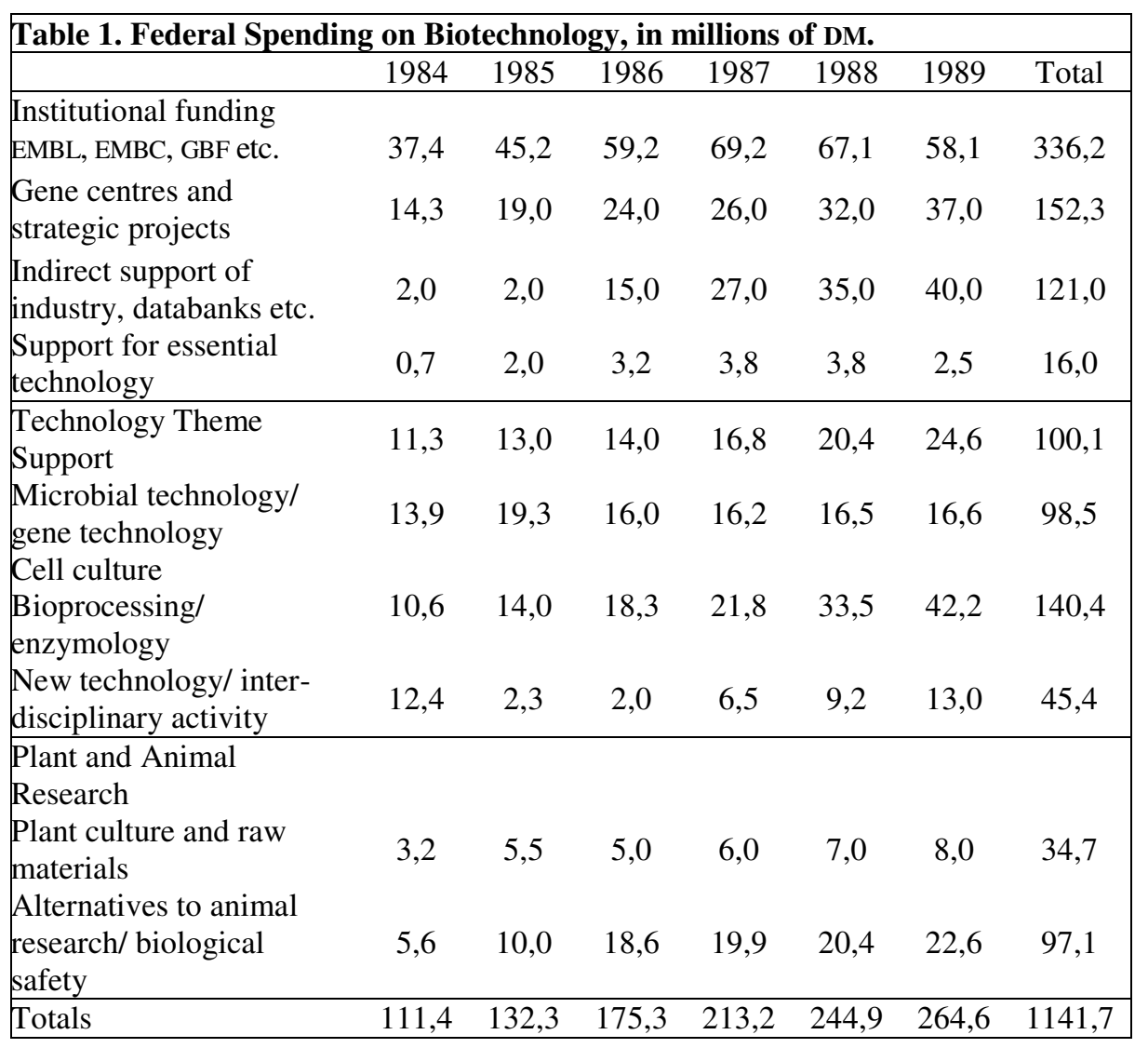

To achieve these ends the BMFT has instituted a process of consultation with Deutschen Forschungsgemeinschaft, DFG, the federal science research funding body; Max-Planck-Gesellschaft, the very wealthy research foundation with institutes both in Germany and abroad; and the Verband der Chemischen Industrie, VCI, the German Chemical Industries Association.

In addition to the broad themes outlined earlier, the BMFT has identified several specific objectives, some of which are detailed in Table 1, above. Many of these 'bottlenecks' require commitment of new manpower resources, available only education at high school and university level is appropriately orientated.

Already mentioned are:
- Genetic manipulation

- Bioprocessing

- Enzymology

- Interdisciplinary measures

At the forefront of much of this work will be the university sector and government research centres, most notably, GBF, Gesselschaft für Biotechnologische Forschung, in Braunschweig and the Kernforschungsanlage, KFA, Julich. These two centres backed by both federal and regional funds have become showpiece institutes. The GBF went through a difficult period in the early 1980s and there was even question of closure. Appointment of the Present Director, Professor Joachim Klein preceded a dramatic turn around in the fortunes of GBF. Strong backing from the regional government of Lower Saxony has been a major spur to success. Like GBF, KFA is strongly backed by local government, North Rhine Westphalia. Dialogue with industry will be an essential component of long terra project planning for both Centres. Most untypically, the BMFT is prepared to consider the funding of projects over a period of up to 15 years.

THE BIOTECHNOLOGY INDUSTRY IN GERMANY

Approximately 100 companies in Germany have a significant involvement in modern biotechnology. Many other companies, notably in the food and beverages sector, have a peripheral involvement. The scope of involvement is very large. Giant firms such as Hoechst are interested in biotechnology in a number of areas from insulin production to insecticide resistance. Small companies such as Biosyntech can offer services such as custom nucleotide or peptide synthesis. On the technical side engineering based companies can supply fermentor and bioprocess technology.

Total industrial biotechnology R\&D expenditure in FRG for 1985 (last year for which results are available) amounts to about DM 700 million, based on biotechnology related sales of DM 20 billion.

To date it is true that the bulk of investment and production has been in the pharmaceuticals and diagnostics sectors. In the long term there will be a gradual increase in the emphasis of agricultural applications and plant genetic engineering. The strong Green movement is a force to be reckoned with, even by the strongest companies. One embarrassing incident involving the Heidelberg based firm Gen-Bio-Tec occurred when they failed to notify the 
Safety Commission of their work on expression of anti-clotting agents in bacteria. Gen-Bio-Tec was at the time in receipt of major Federal and regional support. For weeks the future of that support was placed in doubt.

Facilities to enable new biotechnology start-ups are becoming more available. Venture Capital, in particular, is becoming readily available to firms with a sound technology. Unlike the USA, genuinely high risk investment is unavailable. In the past five years almost thirty significant new start-ups have been established in FRG.

Dechema plays a central role in representing the interests of German biotechnology companies and provides a forum for discussion and debate in the famous Achema congress series. Held every three years Achema is one of Europe's most important shop windows on chemical engineering and biotechnology. Themes treated include sociological issues arising from public concern at issues such as genetic engineering.

The Hannover Biotechnica series of fairs, held annually was launched in 1985 and is already rivalling Achema for prestige in the field of biotechnology. Although backed by Lower Saxony, the Hannover fair has no direct relation with the GBF, although GBF and other local enterprises are given very prominent pavillions.

SECTORIAL CONTRIBUTION OF BIOTECHNOLOGY

Pharmaceuticals is a major business area in FRG, with companies such as Hoechst, Bayer and BASF as giants in the first rank. Medium sized companies include Boehringer-Mannheim, Boehringer-Ingelheim and its pharmaceutical subsidiary Thomae. Henkel, Merck and Schering. All of these have involvements beyond pharmaceuticals. Specialist pharmaceutical companies of medium size would include Behring, Biotest and Knoll. Many of the new start-ups are active in pharmaceuticals and have staffing levels of 5 to 100. Examples of these include Bioferon and the Bissendorf Bio technology Group.

There is a strong emphasis on the latest developments in biotechnology. Pharmaceuticals in trials and production include, insulins, coagulation factors, monoclonal antibodies, urokinase, antiviral agents, interferons, lymphokines, interleukines, TPA, TNF, recombinant vaccines. Market projections for 1995 show a domination by products based on the new technology.
Agriculture is receiving more attention now. Both the Federal and regional governments are defining this as a priority area. Action by the European Commission is helping to focus attention on the prospects for a post subsidy agriculture. The creation of genetically engineered plants is a delicate issue in the FRG. Field release of such plants is subject to fiercely critical scrutiny by both ecologist groups and the governments. The incentive for carrying out such work in Germany is accordingly very small. In university departments, such as Hannover and Bielefeld and at the MaxPlanck Institute for Plant Breeding in Min, work nonetheless continues into such vital goals as increased nitrogen uptake by cereals and other crop plants.

Unless there is a campaign to stimulate awareness of the value of biotechnology for agriculture, it is likely that the industrial contribution to research in Germany will be limited.

Chemical Industry. The application of enzymes to the cost effective production of both raw materials and speciality chemicals in stable bioreactors is receiving dose attention. Centres such as GBF are collaborating with industrial laboratories so as to engineer temperature stable enzymes, capable of working effectively in both aqueous and nonaqueous solvent systems. Microbial leaching and concentration of high value elements and compounds is receiving attention from the metal extraction industry. Many of the large chemical companies are moving into more biological applications areas as the potential of biotechnology becomes apparent. Such activities would include applications of microbial polysaccharides and crude oil recovery.

\section{ENVIRONMENTAL PROTECTION}

The microbial breakdown of waste figures largely in a number of sewage specialist companies. The strong ecological groups in the FRG make it politically expedient for the government of the day to make considerable moves to meet their demands. Biological treatment of effluents with engineered microbes remains unlikely in the present anti-release climate.

University joint ventures are in favour with the government and there is considerable pressure on industry to participate. The new Gene Centres have been founded partly with industrial support.

The University Sector, including the Max-Planck Institutes and state funded institutes still carries out the bulk of research in biotechnology, 
particularly at the precompetitive level. As intimated earlier strategic collaborations with industry are increasing in number and quality, although fears about industrial confidentiality may cause some concern. With government support, general excellence in over 300 departments of biological sciences has crystallised into the formation of four Gene Centres located at Min, München, Heidelberg and Berlin. These centres were established around existing centres of excellence, but the inflow of central funds has allowed the elaboration of new building and equipment.

One of the central weaknesses in the FRG's biotechnology has been the traditional University/Industry divide. The FRG has jealously dung onto the demarcation, well after its abandonment by many other European states. Among academics pure research still has enormous 'cache' compared with applied industrial research. Salary differentials, while significant, do not mean the difference between a bearable and good standard of living. In the FRG academics earn a comfortable living. Biotechnology itself is one of the forces bringing about a reappraisal of the situation as fundamental rapidly becomes applicable. Unfortunately industrial support of 'academic research is concentrated on institutes such as GBF, Braunschweig or KFA Julich, rather than universities 'per se'. Institutes such as the German Cancer Research Centre in Heidelberg have played a useful role in creating a respectable image for applied research. EMBL, the prestigious international laboratory, also in Heidelberg, is also strengthening this consensus by establishing more links with industrial ventures, including the licensing of know-how.

The road to a doctoral level qualification is very long. A diplom awarded at age 25 or 26 must be followed by up to five years research before the award of a doctorate. There is much opposition to changing the system, although many percieve it to be overdue.

CONSEQUENCES OF THE BMFT BIOTECHNOLOGY INITIATIVE

In the context of enabling technology for biotechnology, the BMFT initiative has provided substantial funds for universities to do work in bottleneck areas such as: bacterial physiology, plant physiology and biochemistry and bioprocessing technology (see Table 1).

The Gene Centres are designed to radically upgrade German competence in the field by giving substantial funds and prestige to already recognised centres of excellence. The research aims of these groups are:
- elucidation of genetic structures;

- action and interactions of genes;

- control of gene expression.

The Köln Centre based on the Max-Planck Institute for plant culture research and the University Genetics Institute is concerned with plant genetics and the use of plants for the expression of foreign genes, plant cell culture and micropropagation, the genetic basis for nitrogen fixation. Other work focuses on viral genetics and general aspects of cell biology and biochemistry.

The Heidelberg Centre, located at the university with input from the Cancer Research Centre focuses on microbial genetics, virology and Immunology. Work is targeted at medical problems: diagnosis, therapy, neurobiology etc.

The Munich Centre links the University and the Max-Planck Institute for Biochemistry. Work focuses on the development of sequencing technology and chemical synthesis of genes. Ancillary work in immunology and cell biology builds upon this competence. Plant cell biology focuses on gene transfer.

The Berlin Centre continues the thrust of excellence in gene technology and draws upon the skills of the Max-Planck Institute for Molecular Genetics, which is world renowned. Analogous to the Gene Centres are two BMFT designated Centres of Excellence in bioprocessing technology. These centres are designed to provide a skill and knowledge base for the fundamental skills which underpin commercial processing technology. The first centre has been established in Lower Saxony and receives input from the universities of Braunschweig, Göttingen and Hannover, and the GBF, Braunschweig. GBF is the leading German centre for process and fermentation technology. Its diversification into other areas of biotechnology has secured a status unparalleled.

The Lower Saxony Centre will have its centre of gravity in Braunschweig and will concentrate on the enzymatic and microbial processing of carbohydrates. Antibiotic production processes, animal cell processes, culture development, cell reactions and measuring methodology. Computer and information systems research will support control system 
development and data treatment. Bioreactor development will be an almost automatic consequence of the skill base in Lower Saxony.

The second centre, associated with the University of Stuttgart started work in 1987 and 1988 and consists of five institutes focusing on Bioprocess Engineering, Biochemical Engineering, Applied Microbiology, Applied Genetics and Mammalian Cell Culture.

\section{OtHER STRATEGIC PROJECTS}

The development of biotechnology worldwide demands a flexibility of response from the German research base so as to maintain competitivity. Interdisciplinary fertilisation (electronics/enzyme technology) is seen as critical. New centres could and will be designated as appropriate. Topics under consideration include biocatalysis, chemical synthesis of peptides and genes, protein engineering, etc. New centres will include both institutional and industrial representation to a greater extent than is presently the case for the Gene Centres. GBF has broken this ground by establishing a healthy portfolio of industrially funded projects.

\section{INDIRECT MEASURES}

Might include the financing of studies on aspects of regulation, or the provision of training funds for specific problem areas. The provision of funds in this category is deliberately flexible.

\section{ENCOURAGEMENT OF ENTERPRISE}

The BMFT is keen not to lose the innovative potential of academic staff and especially staff in small and medium scale enterprises in the pharmaceutical and chemical industries, in the food industry. Such innovations could have applications in sectors such as plant biology, industrial scale production, commercial microbiology etc. Bioreactor technology could be encouraged by stimulating joint venture activity between equipment, engineering and research activities. To meet such need funds shall be available to encourage product orientated innovation in biotechnology.

ENCOURAGEMENT OF THE BIOTECHNOLOGY INDUSTRY

Industrial potential in the biotechnology industry is to be reinforced by targeted BMFT support. The basis of support is the provision of training and support for acquisition of the latest in biotechnological methodology. Such support should cushion the risk undertaken by industry active in these areas.
AREAS TO BE TARGETED FOR SUPPORT

- Cell culture

- Gene manipulation

- Process technology using plant animal and human cells and manipulated micro-organisms.

- Enzyme technology for medical and food applications

- Apparatus and equipment development

- Bioreactor development, measurement and control systems

All independent enterprises with an interest in the above areas should be eligible for support up to the level of $40 \%$ of costs to a maximum of DM600 thousand per enterprise. Other funds for personnel, equipment etc are available. Total budget for this programme was fixed at DM100 million over four years from January 1986.

\section{TRAINING FUNDS}

To provide the manpower necessary to sustain growth, the Federal government has designated training as being a major priority and accordingly has provide substantial funds. Training funds are targeted at three areas:

- International scientific collaboration

- Biological chemistry

- Biotechnology further training

Generally speaking the training is orientated towards the areas previously defined as important.

\section{ENCOURAGEMENT OF ACADEMIC/INDUSTRIAL COLLABORATION}

Particularly in the area of precompetitive research it is seen that a dose relationship between factory and university could be beneficial for the Federal Republic. Areas of particular interest in this context would be environmental projects and risk assessment projects that could take place without any threat to industrial security. The work in this area could be chosen on the basis of national and international importance. Flexibility in approach and execution of such projects is seen as essential. To this end the normally detailed and frequent review procedures will give way to a less tightly controlled assessment procedure. The basic project areas could lie in the same theme regions as previously outlined: 
- Microbiology and microbial genetic techniques;

- Cell culture and cell fusion technology;

- Enzyme technology;

- Biological processing (including food technology);

- Plant and animal research;

- Safety research.

Other areas may be defined with the growth of knowledge and experience. The dialogue between science and industry will in itself achieve further definitions. Many areas of development essential to long term industrial competitivity could be developed. In some cases collaborations similar in concept to the British and French club themes would be used to provide enabling technology to a number of client companies and universities.

To identify just a few project areas noted by the BMFT.

\section{Microbial Technology}

Gene transfer technology to improve microbial cell culture yields etc. Genetic stability, ecology and toxicology of mixed microbial cultures. Possible applications of mixed culture techniques.

\section{Cell Culture}

Development, control, standardisation of bioindustrially interesting cell lines

Development of cell storage techniques

Enzymology

Biocatalysis, stability and characterisation of immobilised and carrier associated enzymes, enzyme complexes and cells.

Bioprocessing

Bioreactor mechanics, construction and applications

Evolution of biosensors for process monitoring

\section{Plant and Animal Biology}

Development of plants for food, raw material and environmental applications

Diagnosis, prophylaxis and treatment of animal disease.

\section{Safety and Technology Monitoring}

Development of safer fermentation and bioprocessing technologies for genetically manipulated organisms and their products. Socio-economic aspects of biotechnological developments

\section{New Areas of Applied Biology}

Fusion of biomolecular and microelectronic technologies Enzyme design and protein engineering, gene synthesis

Other areas of significance include: microbial screening, effluent microbiology, microbial collections, gene technology projects, human and animal cell potential, plant cell evaluation, biocatalysis, enzyme production, biocatalyst based production, new bioreactor systems, upstream processing, control technology, plant breeding and raw materials, natural product screening, alternatives to animal research, ecological impact of genetically modified organisms, safety and genetically modified organisms.

INTERNATIONAL COLLABORATION

The BMFT places great importance on collaboration with other EEC member states, especially within the framework of EEC mediated collaborative programmes such as BEP (Biomolecular Engineering Programme), BAP (Biotechnology Action Programme) and projects such as ECLAIR which seek to study alternative, bioindustrial, applications for Europe's agricultural potential.

The OECD initiative in determining regulating principals for molecular genetics is welcomed by the FRG. Collaboration with the OECD is a valuable aspect of international collaboration in biotechnology.

Collaboration with industrial nations is largely focused on Europe and to a lesser extent the United States. Realisation of the Japanese Human Frontiers Programme may well involve German groups.

Collaboration with developing nations is a theme of several recent initiatives. Notably, the GBF Braunschweig has initiated a programme of training specifically targeted at the requirements of developing nations. 


\section{The Role of the GBF, Braunschweig}

The GBF was Europe's first dedicated centre for research and development in biotechnology. After a period of uncertainty, the appointment of the present director, Dr Klein has given GBF a powerful and widely appreciated authority in many areas of biotechnology.

Originally founded by the Volkswagen foundation, the GBF has since 1976 been cofunded by the Federal government $(90 \%)$ and the regional government of Lower Saxony (10\%).

The main research areas of the GBF are:

- Microbial products of synthesis and biotransformation:

- Molecular and cell biology of biologically active proteins;

- Industrial enzymes and protein design;

- Development of bioprocessing.

In addition the GBF has played host to the German Collection of Microorganisms, DSM, since 1979. A separate legal entity, DSM is poised for commercial exploitation as one of the world's foci of microbial strain deposition.

In addition to precompetitive applied research, the GBF has a number of confidential collaborative projects in hand. While GBF can not be as secure as an industrial laboratory, the industrial partners in such contract research have been well satisfied with the GBF's role in such collaborations.

Protein Design was launched as an interest in 1985. In the past year development of hardware and software components of the system has matured and this area looks set to become one of GBF's principal activities. Potential for partnerships with industry and commercial exploitation of this growing know-how is large. The pharmaceutical industry is particularly interested in the prospect of exploiting protein engineering for the production of new or modified biologically active peptides.

The fermentation and bioprocessing facilities of GBF are first rate and already act as a focus for industrial development and pilot studies. The 'Biotechnikum' is equipped with fermenters up to 5.000 liters capacity. Down stream processing facilities can be used to model processes up to semi-industrial scale - a valuable national resource. The 'Biotechnikum Service Unit' gives back-up to process engineering when no commercially obtainable support is available. Such back-up might include the production and isolation of materials not available on the market.

Sophisticated computing and spectrographic facilities back up all aspects of development work, and contribute to a growing excellence in the understanding and implementation of novel process control systems. Licensing of GBF technology is possible, although offered preferentially to German firms.

Almost all of the FRG's major chemical and bioscience companies have entered into collaboration with the GBF in at least one project over the past ten years. Roughly $1 / 3$ of GBF's industrial partners are foreign, the majority from Europe. The opening up of new industrial contacts and ventures is facilitated by an outward looking attitude characterised by seminars and invitations in both industrial and institutional laboratories. The German Chemical Industries Association has created a GBF support group to strengthen industrial appreciation of the resource.

GBF has about 425 staff of whom 160 are scientists. The 1987 budget amounted to almost 70 million DM, including a large 61 element of new building support, which should do much to alleviate the recent overcrowding problems.

GBF has noted the potential of developing countries to benefit from several biotechnological advances. Without adequate training and local expertise such advances cannot be applied. The provision of trained scientists is a choke point which GBF aims to remedy by an in-house training programme. Already three course have sent 60 third world scientists back to their home countries with an appreciation of the modern technologies and their applicability in a third world environment.

Of 250 applicants for the first course the 20 selected included five from Latin America. All costs, including air fare, were born by the GBF.

Lower Saxony has made clear its intention to become the foremost region for German biotechnology. Recently it became committed to supporting three biocentres collaborating with the GBF, Braunschweig Technical University, the University of Hannover and the University of Göttingen. This structure will give the area a solid mass of excellence. The only problem foreseen is that of staff recruitment. 
Growth in biotechnology is characterised by the rapid expansion of the Bissendorf Biotechnology group. Next to GBF they have launched a major peptide and protein production centre, Braunschweiger Biotechnologie. 